DOI: https://doi.org/10.34069/AI/2021.43.07.17

How to Cite:

Shumeiko, T., Kurkova, K., Yarova, R., Nemesh, P., \& Zubko, O. (2021). Legislative prerequisites for the classification of arm. Amazonia Investiga, 10(43), 168-174. https://doi.org/10.34069/AI/2021.43.07.17

\title{
Legislative prerequisites for the classification of arm
}

\section{Законодавчі передумови класифікації зброї}

\author{
Received: July 9, $2021 \quad$ Accepted: August 15, 2021
}

\author{
Written by: \\ Tetiana Shumeiko ${ }^{62}$ \\ https://orcid.org/0000-0003-0103-300X \\ Kseniia Kurkova ${ }^{63}$ \\ https://orcid.org/0000-0002-4259-5511 \\ Ruslana Yarova ${ }^{64}$ \\ https://orcid.org/0000-0001-5525-1059 \\ Petro Nemesh $^{65}$ \\ https://orcid.org/0000-0002-1776-9081 \\ Oksana Zubko ${ }^{66}$ \\ https://orcid.org/0000-0003-4682-6468
}

\begin{abstract}
The purpose of the article is to analyze the approaches to the classification of weapons, which are enshrined in official Draft Laws, to highlight their shortcomings and contradictions, as well as justify the author's view on this issue. The subject of the study is the Bills regulating the issue of classification of weapons, which are currently under consideration in the Verkhovna Rada of Ukraine. The research methodology includes general scientific and special methods of legal science: historical and legal, normative and dogmatic, dialectical, comparative and legal, logical, monographic, legal and predicting. Results of the research. The general characteristic of the legislative approaches to the classification of arms enshrined in the Draft Laws, which are under consideration of the Verkhovna Rada of Ukraine, is given. Their similarities and differences are revealed, as well as the advantages and disadvantages. Practical implication. The practical value of the legislative consolidation of the classification of arms is substantiated, the limits of its application are determined. Value / originality. On the basis of the research the conclusion on necessity of development and legislative acceptance of the
\end{abstract}

\begin{abstract}
Анотація
Метою статті $\epsilon$ аналіз та узагальнення підходів до класифікації зброї, які закріплені в офіційних законопроектах, висвітлення їх недоліків та суперечностей, а також обгрунтування авторського погляду на дане питання. Предметом дослідження $\epsilon$ законопроекти, що регламентують питання класифікації зброї, і які наразі перебувають на розгляді в Верховній Раді України. Методологія дослідження включає загальнонаукові та спеціальні методи юридичної науки: історико-юридичний, нормативно-догматичний, діалектичний метод, порівняльно-юридичний, логічний, монографічний, правового моделювання. Результати дослідження. Надається загальна характеристика законодавчим підходам до класифікації зброї, викладеним у законопроектах, що перебувають на розгляді Верховної Ради України IX скликання. Виявляються їх схожі та відмінні риси, а також з'ясовуються їх переваги та недоліки. Практичне значення. Обгрунтовується практична цінність законодавчого закріплення класифікації зброї, визначаються межі iï застосування. Цінність /
\end{abstract}

\footnotetext{
${ }^{62} \mathrm{PhD}$ in Law, Doctoral Student of the Police Law Department of the National Academy of Internal Affairs, Ukraine.

${ }^{63}$ Doctor of Law, Senior Researcher of the Scientific Institute of Public Law, Ukraine.

${ }^{64} \mathrm{Ph} . \mathrm{D}$ in Law, Associate Professor of the Department of Constitutional and Administrative Law of the National Transport University, Ukraine.

${ }^{65} \mathrm{PhD}$ in Law, Professor of the Department of Civil Law and Procedure, Uzhhorod National University, Ukraine.

${ }^{66}$ Ph.D. in Law, Post-Doctoral Student, Scientific Institute of Public Law, Kyiv, Ukraine.
} 


\section{AMAZONIA
Investiga}

branched classification of all kinds of the weapon is made, and also author's offers on the given question are formulated.

Key words: arms, arms circulation, classification of arms, firearms, types of arms.

\section{Introduction}

The arms trade is one of the most important spheres of public relations in any country, as it is directly related to the exercise of the constitutional right to active self-defense by the citizens. Thus, most democracies (not only European but also post-Soviet ones) have already developed a well-articulated legislative framework on the circulation of firearms. However, this does not apply to Ukraine, where the Soviet rudiments of the mechanism of legal regulation of this issue still prevail. In particular, we are talking about the Instruction on the procedure for manufacture, purchase, storage, accounting, transportation and use of firearms, pneumatic, melee weapons, domestically manufactured devices for firing cartridges, equipped with rubber or similar non-lethal metal shells, and cartridges to them, as well as their ammunition, main parts of weapons and explosives, which was approved by a number of bylaws of a departmental nature. Jointly, they constitute an unsystematic, fragmented and obsolete regulatory framework for arms trafficking in Ukraine, which in turn is the main cause of numerous legal conflicts, gaps and contradictions, as well as unequal application of legislation and, as a consequence, violation of the constitutional rights and freedoms of an individual and a citizen.

Under such circumstances, the issue of the need for a comprehensive legislation on weapons has long been beyond doubt and objection. However, due to the contradictory nature of many issues related to the circulation of weapons, the drafting of such an act has been going on for more than 20 years and during that time parliamentarians have not been able to find the most compromise option for legal ownership of weapons. Among the unresolved issues are the functioning of the State register of weapons, outlining the basic rules of civilian circulation of weapons, establishing general procedure for obtaining the right to bear arms, determining the basic principles of using weapons for self-defense, etc. The approaches to the classification of weapons оригінальність. На основі проведеного дослідження робиться висновок про необхідність розробки та законодавчого ухвалення розгалуженої класифікації усіх видів зброї, а також формулюються авторські пропозиції з даного питання.

Ключові слова: вогнепальна зброя, зброя, категорії зброї, класифікація зброї, обіг зброї.

are also ambiguous, so we propose to analyze them in more detail.

Thus, the purpose of this scientific article is to analyze and summarize the approaches to the classification of weapons, which are enshrined in the Draft Laws, highlight their shortcomings and contradictions, as well as to justify the author's view on this issue.

\section{Methodology}

In order to achieve the goal of the Article, the following methods of scientific knowledge were used.

Thus, comparative and historical and legal method is applied to examine the enactment of legislation, which regulates the relations in the area of arms trafficking in Ukraine at different historical stages of the State's development.

Normative-dogmatic method helps to analyze the Draft Laws on the weapon, which are currently under consideration in the Verkhovna Rada of Ukraine (the Draft Law No. 1222; the Draft Law No. 1222-1; the Draft Law No. 4335; the Draft Law No. 4335-1; the Draft Law No. 5708).

Method of comparative analysis is useful when characterizing the rules of the bills mentioned above, which enshrine the types of the arms that are in circulation in our country.

Logical method is used to identify the advantages and disadvantages of the proposed statutory classifications.

With the help of monographic method the classifications of the types of weapon, which are based on different features, proposed by some foreign and domestic scholars are studied.

Legal and predicting method makes it possible to draw the relevant conclusions. 


\section{Literature Review}

According to the purpose for use by the relevant subjects, as well as the main parameters and characteristics of the weapon is divided into: combat; staff; civil, which is classified as follows: a) hunting; b) sports; c) self-defense; museum, antique (historical).

By type: firearm; cold; gas; pneumatic.

By method of manufacture: industrial; artisanal; unauthorized.

This classification is general and, in turn, can be divided into smaller types, types, systems, models, samples of weapons (Romanov 2005, p. 36).

The main types of weapons include: a) firearms a weapon in which the charge (bullet, shield, etc.) is triggered by the instantaneous release of chemical energy of the charge (gunpowder or other explosive mixture); b) sporting firearms, which include sporting pistols, revolvers, rifles intended for use for sports purposes, as well as smoothbore rifles; c) hunting firearms are hunting rifles, smoothbore rifles with "paradox" holes with slits of $100-140 \mathrm{~mm}$ from the beginning and end of the barrel, hunting rifles with "supra" holes, combined rifles with smooth rifled barrels, and also hunting small-caliber rifles. The length of the barrels of smoothbore rifles must be not less than $450 \mathrm{~mm}$, and the total length of the weapon - not less than $800 \mathrm{~mm}$; d) pneumatic weapons, which include pistols, revolvers, rifles of caliber more than $4.5 \mathrm{~mm}$ with a bullet speed of more than 100 meters per second, in which the charge is driven by compressed gases; e) cold steel - devices and objects structurally designed to hit the target by muscular force of a person or a mechanical device (can be cold, hand and cold metal) (Paranytsya and Babich, 2017, p. 190).

Ruchkin (2003, p. 8), listing the types of weapons that are part of the system of individual weapons, defines gas and electroshock devices as weapons.

Bilenchuk (2003, p. 101), include non-lethal weapons, for example, smooth-bore firearms of special purpose, when classifying certain types of weapons. The same view is shared by Kofanov and Kofanova (2019). Missliwetz and others (1999), in their turn, consider pump-gun as a weapon, stating that their injuries and wound mechanisms have specific features.
According to some authors, all firearms, whether military assault rifles or civilian pistols, are classified into three broad categories: fully automatic, semiautomatic and other. The groupings are based on how the weapon fires and loads bullets into its chamber for the next firing (The New York Times, 1989).

Laurance (1998, p. 17) highlights small arms (revolvers and self-loading pistols, rifles and carbines, sub-machine guns, sub-machine guns, assault rifles, machine guns), light arms (handheld under-barrel and mounted grenade launchers, portable anti-aircraft guns, portable anti-tank guns, recoilless rifles, portable launchers of anti-tank missile and rocket systems, portable launchers of anti-aircraft missile systems, mortars of calibers up to $82 \mathrm{~mm}$ inclusive), ammunition and explosives (cartridges (rounds) for small arms, shells, missiles and mines for light weapons, mobile containers with missiles or shells for single action anti-aircraft and anti-tank systems, antipersonnel and anti-tank hand grenades, anti-tank mines).

\section{Results and Discussion}

Scientists have always been interested in the classification of weapons. Thus, there is an extremely large number of classifications of weapons diverse in content and volume in the domestic legal literature. However, this issue has also begun to interest the legislator in recent years given its practical value. In particular, the Verkhovna Rada of Ukraine of the 9th convocation is currently considering five bills aimed at regulating the sphere of arms circulation in Ukraine and which to some extent affect the issue of their classification, namely:

Draft Law of Ukraine "On Weapons" No. 1222 of September 2, 2019 (hereinafter - the Draft Law No. 1222);

Draft Law of Ukraine "On Arms Circulation" No. 1222-1 of September 20, 2019 (hereinafter - the Draft Law No. 1222$1)$;

$\square \quad$ Draft Law of Ukraine "On Circulation of Civilian Firearms and Ammunition" No. 4335 of November 6, 2020 (hereinafter - the Draft Law No. 4335);

$\square \quad$ Draft Law of Ukraine "On Civil Weapons and Ammunition" No. 4335-1 of November 24, 2020 (hereinafter - the Draft Law No. 4335-1);

$\square \quad$ Draft Law of Ukraine "On the Right to Civilian Firearms" No. 5708 of June 25, 2021 (hereinafter - the Draft Law No. 5708). 


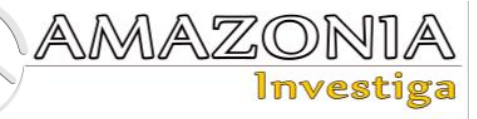

One does not need to go into the detailed analysis of the content of these bills; one just need to read their name to understand that they have different scope. For example, some bills regulate just the circulation of weapons, and others - the circulation of weapons and ammunition; the scope of some bills extends to the circulation of all weapons, while the others - to the circulation of just firearms, or just civilian weapons.

Different scope of legal regulation of the circulation of weapons leads to the application of different approaches to the classification of weapons, because it is the main subject of legal regulation of these bills. Below we will try to find out what exactly is the difference.

1. The Draft Law No. 1222, which was submitted to the Verkhovna Rada on September 02, 2019 by the People's Deputies of Ukraine I. Fris Matusevych and O. Matusevych, provides that all civilian weapons and ammunition in civilian circulation (turnover) in Ukraine are divided into four categories (Article 3 of the Draft Law):

The first category is pneumatic weapons caliber up to $4.5 \mathrm{~mm}$ and the speed of the metal element up to $100 \mathrm{~m} / \mathrm{s}$; firearms under the Flaubert cartridge up to $4.5 \mathrm{~mm}$ caliber and ammunition for it; gas weapons; bows and crossbows with a string tension of not more than $40 \mathrm{~kg}$; other weapons that do not belong to the second, third, or fourth category and are not prohibited in civilian circulation;

The second category is long-barreled smoothbore firearms; pneumatic weapons with a caliber of more than $4.5 \mathrm{~mm}$ and a flight speed of the metal element of more than $100 \mathrm{~m} / \mathrm{s}$; firearms under the Flaubert cartridge caliber over $4.5 \mathrm{~mm}$ and their ammunition, bows and crossbows, not included in the first category;

The third category is long-barreled firearms, combined firearms and their ammunition;

The fourth category is short-barreled firearms and ammunition for it; short-barreled smoothbore firearms designed for firing ammunition equipped with less lethal elastic propellants and their ammunition.

The main disadvantage of this classification of weapons, in our opinion, is its limited nature, as it does not cover all types of weapons, which are mentioned not only in other regulations, but even in the Draft Law itself. In particular, the weapons in question are «simulation» and «deactivated» weapons, «automatic» and «semi-automatic», «training», «reward», «signal», «service» weapon, etc.

Another significant drawback is the use in the classification of some types of weapons, the definition (description) of which is absent in the relevant articles of the Daft Law. First of all, we are talking about Flaubert Gun, as well as "bows" and "crossbows".

2. Draft Law No. 1222-1, which was submitted to the Verkhovna Rada on September 20, 2019 by the People's Deputies of Ukraine O. Bakumov, V. Medianyk, P. Sushchenko and others, provides for the division of weapons and ammunition into four categories. At the same time, other names are used in this Draft Law for the following categories and they have a fundamentally different content:

Category A, which includes automatic weapons; rifled weapons with a caliber of more than 12.7 $\mathrm{mm}$; firearms disguised as other objects; firearms made of materials that do not allow to detect them with the help of metal detectors; armourpiercing ammunition (ball of hard armourpiercing action), explosive (bullet with a charge that explodes at the moment of collision) or incendiary (bullet with a chemical mixture that ignites in contact with air or at the time of collision), as well as shells for such ammunition; ammunition specially designed to enhance penetration and damage to protected targets, as well as shells for such ammunition;

Category B, which includes: short-barreled weapons, except for automatic and smooth-bore short-barreled (traumatic) weapons;

Category $\mathrm{C}$, which includes weapons that do not fall into other categories, such as: smooth-bore short-barreled (traumatic) weapons; rifled longbarreled weapons; combined long-barreled weapons; air guns; smoothbore long-barreled weapons; exhausted weapons; museum weapons and other deactivated weapons that are not included in other types of deactivated weapons; Category D, which includes melee weapons.

The above classification of weapons has the same shortcomings as the previous one, as well as some additional ones.

Firstly, it does not cover all the weapons mentioned in the Draft Law itself. In this case, we are talking about "award" weapons, as well as "gas" weapons.

Secondly, it mentions some types of weapons, the definition (description) of which is absent in 
the relevant articles of the bill. In this case, we are talking about "ammunition specially designed to enhance the penetrating action and defeat the protected targets"; "Ammunition shells".

Thirdly, it does not follow one of the basic principles of classification - the principle of reciprocity and comprehensiveness, which provides for maximum consideration of all objects that meet certain requirements.

So, for example, it is not clear to what category the rifled weapon with a caliber less than 12.7 $\mathrm{mm}$ belongs if it is not long-barreled; under which categories smooth-bore non-traumatic weapon or combined short-barreled weapons should be classified.

Fourthly, it uses terms that do not have clear criteria for identification and require a subjective approach when explaining them. In particular, we are talking about such terms as "firearms disguised as other objects", "firearms made of materials which cannot be identified by metal detectors", "other deactivated weapons that are not included in the category "types of deactivated weapons".

3. Draft Law No. 4335, which was submitted to the Verkhovna Rada on November 06, 2020 by the People's Deputies of Ukraine I. Fris, O. Bakumov, O. Fediienko and others, differentiates all civilian firearms into five categories:

Category A, which includes automatic firearms; Category B, which includes smooth-bore shortbarreled firearms (traumatic);

Category $\mathrm{C}$, which includes short-barreled firearms;

Category D, which includes long-barreled smooth-bore firearms;

Category E, which includes long-barreled rifles and combined firearms.

At first glance, the above classification of weapons is balanced and unified. However, a more detailed analysis of its content can reveal a number of significant shortcomings, most of which were analyzed above.

Firstly, it does not provide for the description of all the weapons mentioned in the Draft Law itself (like two previous classifications). In particular, such categories as "semi-automatic firearms", "devices for sound or light signals", "revolvers", "signal weapons", "antique" firearms, "copy of antique weapons", "award weapons", "training and dissecting weapons", as well as their ammunition and ammunition are not described.

Secondly, it does not comply with one of the main principles of classification - the principle of reciprocity and comprehensiveness, which provides for maximum consideration of all objects that meet certain requirements. Thus, for example, it is not clear under which category pneumatic weapon of caliber more than $4,5 \mathrm{~mm}$ and speed of flight of a metal element more than $100 \mathrm{~m} / \mathrm{s}$, as well as devices under the Flaubert cartridge of caliber more than 4,0 $\mathrm{mm}$ if energy of a bullet makes more than $0.5 \mathrm{~J} / \mathrm{mm} 2$ should be classified.

Thirdly, it is difficult to understand by which arguments the authors of the Draft Law were guided by when referring to different categories of "smooth-bore short-barreled firearms" and other "short-barreled firearms".

4. Draft Law No.4335-1, which was submitted to the Verkhovna Rada on November 24, 2020 by the People's Deputy of Ukraine A. Sharaskin, mentions four categories of civilian weapons:

Category A, which includes automatic firearms; Category B, which includes long-barreled smoothbore firearms, pneumatic weapons with a caliber of more than $4.5 \mathrm{~mm}$ and a firing speed of more than $150 \mathrm{~m} / \mathrm{s}$, weapons with a Flaubert cartridge of more than $4 \mathrm{~mm}$ caliber;

Category C, which includes short-barreled firearms and smooth-bore short-barreled firearms (less lethal);

Category $\mathrm{D}$, which includes long-barreled rifled and combined firearms.

The following gaps of the above classification are among the most significant ones.

Firstly, it does not cover all the types of weapons mentioned in the relevant Draft Law (like all the classifications we analyzed above). In particular, this applies to "semi-automatic firearms", "service weapons, "award weapons", "signal weapons", "ammunition", as well as "replicas of antique weapons" and "antique firearms", which do not fall under the features defined in Part 2, Article 2 of this Draft Law.

Secondly, it mentions some types of weapons, the definition (description) of which is absent in the relevant articles of the Draft Law. In particular, this applies to Flaubert Gun. 


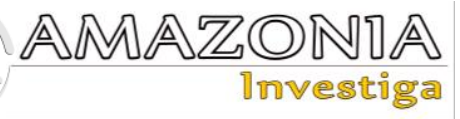

Thirdly, it does not follow one of the main principles of classification - the principle of reciprocity and comprehensiveness, which provides for maximum consideration of all objects that meet certain requirements. In particular, it is not clear under which categories "pneumatic devices with a caliber of more than $4.5 \mathrm{~mm}$ and a firing speed of less than $150 \mathrm{~m} / \mathrm{s}$ " should be classified.

5. Draft Law No. 5708, which was submitted to the Verkhovna Rada of Ukraine on June 25, 2021 by the People's Deputies of Ukraine I. Fris, M. Buzhanskyi, I. Yunakov, and others, defines five categories of civilian firearms, which in their content are completely identical to the categories defined in the Draft Law No. 4335. Therefore, this classification has all the same shortcomings that we have identified above.

\section{Conclusion}

The sphere of arms trafficking is almost the least regulated area of public life in Ukraine nowadays. Active legislative work, as well as significant amount of scientific researches on this issue, has long failed to yield the expected results; the quality of legal regulation of this important issue remains extremely low (Shumeiko et al. 2021, p. 198).

Thus, having analyzed the main approaches to the classification of weapons, which are presented in the Draft Laws, which are currently under consideration in the Verkhovna Rada of Ukraine, we can draw the following conclusion: all legislative approaches to the classification of weapons have a number of significant shortcomings, without the elimination of which their practical application would be accompanied by numerous conflicts and contradictions, and therefore will need official explanation and scientific interpretation.

In our opinion, the legal definition of the main categories of weapons should be based not only on the peculiarities of the legal regime of circulation of certain types of weapons, but also on its other classification features. In particular, the analysis of the main provisions of the Draft Laws on weapons, which are currently being considered by the Verkhovna Rada of Ukraine, allowed us to identify several criteria for the classification of weapons:

Depending on the general principle of operation, one can highlight firearms, gas, pneumatic, electropneumatic, melee weapons, devices for sound or light signals, objects whose shape is designed to resemble weapons, structurally similar to weapons products, etc.

$\square \quad$ Depending on the scope of application, one can highlight military weapons, service weapons, civilian weapons.

$\square \quad$ Depending on the length of the barrel, one can single out short-barreled and longbarreled weapons.

$\square$ Depending on the presence of cuts in the guide section of the barrel, one can single out rifled, smoothbore and combined weapons.

Depending on the recharging mechanism, automatic and semi-automatic weapons can be distinguished.

$\square \quad$ Depending on the purpose, you can identify military, hunting, sports, recreational, training (educational), museum, historical (antique), award, signal and other weapons.

$\square \quad$ Depending on whether used for the purpose intended, one can single out deactivated (neutralized) weapons, simulating weapons, training and dissecting weapons, models or copies of weapons, replicas of ancient (antique) weapons, etc.

Summarizing the above, we can state that the following criteria should be taken into account as the basis for any legislative differentiation of weapons into certain categories:

firstly, the scope of legal regulation of the Draft Law;

secondly, legal regime of weapons ownership; thirdly, the differences between the different types of weapons that underlie their classifications according to various scientifically sound criteria.

Only if all these criteria are taken into account can the legally defined categories of weapons be successfully applied in practice.

\section{References}

Bilenchuk, P. (2003). Ballistics: forensic firearms: textbook for universities. Kyiv: International Agency "BeeZone". https://voenka.kiev.ua/products/balistikakriminalistichne-vognestrilne-zbroeznavstvoDraft Law No. 1222. Official Web site of the Verkhovna Rada of Ukraine, Kyiv, Ukraine, September $\quad 02,2019$. http://w1.c1.rada.gov.ua/pls/zweb2/webproc4_2 ?id $=\&$ pf3516 $=1222 \&$ skl $=10$

Draft Law No. 1222-1. Official Web site of the Verkhovna Rada of Ukraine, Kyiv, Ukraine, September 20, 2019. 
http://w1.c1.rada.gov.ua/pls/zweb2/webproc4_1 ?pf3511=66918.

Draft Law No. 4335. Official Web site of the Verkhovna Rada of Ukraine, Kyiv, Ukraine, November 06, 2020. http://w1.c1.rada.gov.ua/pls/zweb2/webproc4_1 ?pf3511=70363.

Draft Law No. 4335-1. Official Web site of the Verkhovna Rada of Ukraine, Kyiv, Ukraine, November 24, 2020. http://w1.c1.rada.gov.ua/pls/zweb2/webproc4_1 ?pf3511=70512.

Draft Law No. 5708. Official Web site of the Verkhovna Rada of Ukraine, Kyiv, Ukraine, June 25 , 2021. https://w1.c1.rada.gov.ua/pls/zweb2/webproc4_ 1 ?pf3511=72360.

Kofanov, A., \& Kofanova, O. (2019). Forensic investigation of firearms, cartridges and gunshot residue (forensic ballistics). Criminalist's Scientific Library. Kyiv. http://elar.naiau.kiev.ua/bitstream/123456789/1 0710/1/\%D0\%9A\%D0\%BE\%D1\%84\%D0\%B0 $\% \mathrm{D} 0 \% \mathrm{BD} \% \mathrm{D} 0 \% \mathrm{BE} \% \mathrm{D} 0 \% \mathrm{~B} 2 \% 20 \% \mathrm{D} 0 \% \mathrm{BF} \%$ D1\%80\%D0\%B0\%D0\%BA\%D1\%82\%D0\%B8 $\% \mathrm{D} 0 \% \mathrm{BA} \% \mathrm{D} 1 \% 83 \% \mathrm{D} 0 \% \mathrm{BC} \% 2018.12 .18$.pdf Laurance, E.J. (1998). Light Weapons and Intrastate Conflict: Early Warning Factors and Preventive Action. Report to the Carnegie Commission on Prevention Deadly Conflict. USA: Carnegie Corporation of New York.

Missliwetz, J., Risser, D., Bauer, G., Reiter, C., Denk, W., Mortinger, H., \& Stellwag-Carion, C. (1999). Pump-gun as a weapon. Type of injuries, prohibition of weapons. Archives for criminology, 203(1-2), pp. 10-18.

Paranytsya, S. and Babich, V. (2017). The special feathers of administrative legal classification of the kinds of firearms. Lviv Polytechnic National University Institutional Repository.

http://ena.lp.edu.ua. http://ena.lp.edu.ua:8080/bi tstream/ntb/41807/2/2017n876_Paranytsya_SThe_special_feathers_188-192.pdf

Romanov, O. (2005). "Arms: legal aspect". Legal Journal, 2(32), pp. 32-38. http://ebd.mdu.in.ua/cgi-

bin/irbis64r_12/cgiirbis_64.exe?LNG=en\&C21 $\mathrm{COM}=\mathrm{S} \& \mathrm{I} 21 \mathrm{DBN}=\mathrm{EKS} \& \mathrm{P} 21 \mathrm{DBN}=\mathrm{EKS} \& \mathrm{~S} 21$ FMT $=$ briefwebr\&S21 ALL $=\% 28 \% 3 \mathrm{C} \% 2 \mathrm{E} \% 3 \mathrm{E}$ K\%3D\%D0\%97\%D0\%B1\%D1\%80\%D0\%BE $\% \mathrm{D} 1 \% 8 \mathrm{~F} \% 3 \mathrm{C} \% 2 \mathrm{E} \% 3 \mathrm{E} \% 29 \& \mathrm{Z} 21 \mathrm{ID}=\& \mathrm{~S} 21 \mathrm{SR}$ $\mathrm{W}=\& \mathrm{~S} 21 \mathrm{SRD}=\& \mathrm{~S} 21 \mathrm{STN}=1 \& \mathrm{~S} 21 \mathrm{REF}=10 \& \mathrm{~S} 2$ $1 \mathrm{CNR}=20 \& \mathrm{FT} \_$REQUEST $=\& F T \_P R E F I X=$

Ruchkin, V. (2003). Arms and traces of their use: Forensic doctrine. Monograph. Moskow: Jurlitinform.

Shumeiko, T., Kovalenko, V., Hurkovskyy, M., Legenkyi, M., \& Komirchyi, P. (2021). The main directions of State policy in the area of arms trafficking in Ukraine. Amazonia Investiga, 10(38), 197-203. https://doi.org/10.34069/AI/2021.38.02.19. https://amazoniainvestiga.info/index.php/amazo nia/article/view/1557/1550

The New York Times. (1989). How Guns Are Classified.

https://www.nytimes.com/1989/02/21/us/howguns-are-classified.html 